\title{
The effects of biofilter on the removal of greenhouse gases at anaerobic digestion plants
}

\author{
Khả năng loại bỏ khí gây hiệu ưng nhà kính của các bể lọc khí sinh học tại các \\ nhà máy xử lý chất hưu co bằng biện pháp ky khí
}

Research article

Nguyen, Thanh Phong ${ }^{*} ;$ Clemens, Joachim ${ }^{2}$; Cuhls, Carsten ${ }^{3}$

${ }^{I}$ Faculty of Science and Technology, Hoa Sen University, 8 Nguyen Van Trang, District 1, HCM City, Vietnam; ${ }^{2}$ Faculty of Agriculture, University of Bonn, Karlrobert-Kreiten Str. 13, 53115 Bonn, Germany; ${ }^{3}$ Ingenieurgesellschaff für Wissenstransfer, Gewitra mbH, Im Moore 45, 30167 Hannover, Germany

\begin{abstract}
This study investigated the removal of gases such as methane (CH4), nitrous oxide (N2O) and ammonia (NH3) from biofilters in nine anaerobic digestion plants in Germany that treat biowaste. The treatment is in form of mechanical pre-treatment, anaerobic digestion followed by a composting with or without intensive aeration. The exhaust gases from the mechanical and anaerobic steps are treated by biofilters. In average, the biofilters removed $30 \%$ of total organic carbon (TOC), $50 \%$ of non-methane volatile organic carbon (NMVOC) and $51 \% \mathrm{NH} 3$, whereas $\mathrm{N} 2 \mathrm{O}$ concentrations increased by $26 \%$. For $\mathrm{CH} 4$ the biofilters had only a small removal effect $(6 \%)$.

Nghiên cưu khảo sát sụ loại bỏ nhũng khí gây hiệu ưng nhà kính nhu $\mathrm{CH}_{4}, \mathrm{~N}_{2} \mathrm{O}$ và $\mathrm{NH}_{3}$ tù nhũng bể lọc khí sinh học ở chín nhà máy xủ lý rác thải hữu co ở nước Đức bằng các biện pháp kỵ khí và hiếu khí. Rác hũu co được xử lý ở nhà máy thông qua các biện pháp nhu tiền xư lý bằng co học, ky. khi và tiếp theo là hiếu khí với công nghệ thổi khi chủ động hoặc không thổi khí chủ động. Khí thải tù các quá trình co học và ky khí được xủ lý bằng biện pháp lọc khí sinh học trước khi thải ra môi trương. Trung bình, nhũng bể lọc khi sinh hoc loại bỏ 30\% tổng luọng carbon hũu co, 50\% nhũng chất carbon hũu co bay hơ nhung không phải khi methane và 51\% khi ammoniac. Trong khi đó, nồng độ khi $\mathrm{N}_{2} \mathrm{O}$ tăng lên 26\% sau khi qua bể lọc khí sinh học. Đối với khí methane, bể lọc khí sinh học có hiệu suất loại bỏ với loại khi này rất thấp chỉ $6 \%$.
\end{abstract}

Keywords: greenhouse gas, emissions, composting, windrows, organic waste, methane, biofilter

\section{Introduction}

Anaerobic digestion (AD) for treatment of biowaste is rapidly gaining interest in Germany (Mata-Alvarez et al., 2000; Fricke et al., 2005). The treatment is essentially based on the activities of microorganisms that transform organic substances into biogas (Appels et al., 2008). Biogas is used as renewable energy source, and nutrients in the residue can be recovered in agriculture as fertilizer or soil conditioner (Møller et al., 2009). In addition, AD of biowaste is attracting attention as an effective method to reduce greenhouse gas (GHG) emissions according to Kyoto protocol (Møller et al., 2009). According to the life cycle analysis (LCA), AD results in negative GHG emissions. The total GHG emissions for $\mathrm{AD}$ can reduce up to one tonne $\mathrm{CO}_{2}$ equivalent/ $\mathrm{Mg}$ separated organic waste (Sanscartier et al., 2011).
Actually, many studies have been conducted to show the benefits of AD treatment, for instance the works of Bockreis and Steinberg (2005), Fricke et al., (2005), Zupančiča, (2008) and Møller et al., (2009). In fact, AD plants may have fugitive emissions of $\mathrm{CH}_{4}, \mathrm{~N}_{2} \mathrm{O}$ and $\mathrm{NH}_{3}$.

$\mathrm{CH}_{4}$ and $\mathrm{N}_{2} \mathrm{O}$ are considered to be strong greenhouse gases (GHGs), whereas $\mathrm{NH}_{3}$ is identified as an odour component and an indirect GHG. According to the Intergovernmental Panel on Climate Change (IPCC, 2007), the global warming potential of $\mathrm{CH}_{4}$ and $\mathrm{N}_{2} \mathrm{O}$ in 100 years are respectively 25 and 298 times higher than $\mathrm{CO}_{2}$. According to Insam and Wett (2008), $\mathrm{CH}_{4}$ is the major contributor to GHG emissions from waste treatment. Landfills and waste water are the largest sources of $\mathrm{CH}_{4}$ emissions, accounting for $90 \%$ of $\mathrm{CH}_{4}$ emissions linked to the waste sector. In developed countries, $\mathrm{CH}_{4}$ produced in 
landfills is collected and used as a renewable energy source (Bogner et al., 2008).

Exhaust gases from the encapsulated parts of AD plants are treated by biofilters before they are released into the atmosphere. In a biofilter, waste gas passes biofilter material (e.g. wood chip and root bark) and organic compounds are degraded by microorganisms (Hort et al., 2009). The performance of a biofilter depends on the composition of the exhaust gas, packing material, nutrient supply, temperature, $\mathrm{pH}$, pressure drop and residence time (Deshusses et al., 1999).

The aim of the study was to investigate the biofilter's efficiency. The biofilters in nine operating AD plants in Germany, two wet digestion plants, four dry digestion plants and three solid digestion plants, were evaluated.

\section{Materials and methods}

\subsection{Measured locations}

Fifteen biofilters at nine AD plants were investigated in the study. The gas before and after biofilter was analysed at each plant for 1 week. At capsuled biofilters the treated air left the biofilter in a chimney. Here the gases were measured. At open biofilter, $16 \mathrm{~m}^{2}$ of the biofilter $(4 \mathrm{x} 4 \mathrm{~m})$ was covered by a thin foil. Concentrations of the treated gases were measured under the foil (Figure 1).

At two AD plants, acid scrubbers were used to eliminate $\mathrm{NH}_{3}$. High $\mathrm{NH}_{3}$ concentrations in the raw gas should be removed by acid scrubbers. To evaluate the $\mathrm{NH}_{3}$ and other gases such as TOC, $\mathrm{CH}_{4}$ and $\mathrm{N}_{2} \mathrm{O}$ removal efficiencies of the acid scrubbers. The concentrations of $\mathrm{NH}_{3}$, TOC, $\mathrm{CH}_{4}$ and $\mathrm{N}_{2} \mathrm{O}$ at the inlet and outlet of the acid scrubbers were measured.

\subsection{Emission determinations}

Continuously monitored parameters included TOC, $\mathrm{CH}_{4}$ and $\mathrm{N}_{2} \mathrm{O}$. TOC was measured by flame ionisation detector (FID) (Bernath Atomic 3006) while $\mathrm{CH}_{4}$ and $\mathrm{N}_{2} \mathrm{O}$ were measured by an infrared gas analyser (ABB). Gas concentrations in the treated and untreated exhaust air were recorded every minute. To control the accuracy of the infrared gas analyser, exhaust gases were sampled manually by evacuated headspace vials and subsequently analysed on $\mathrm{CH}_{4}$ and $\mathrm{N}_{2} \mathrm{O}$ by gas chromatography (ECD/FID) in the laboratory. A manual discontinuous analysis was applied for $\mathrm{NH}_{3}$ measurement: $\mathrm{NH}_{3}$ was extracted from the waste gas stream by absorbing it in sulfuric acid and subsequently measured colorimetrically in the laboratory. $\mathrm{NH}_{3}$ samples of treated and untreated gases were collected twice. Air fluxes to the biofilter were measured by an anemometer (testo 435) or micromanometer (Müller Instruments EPM-300-BA, Germany). It was assumed that the volumes of treated and untreated air were the same.

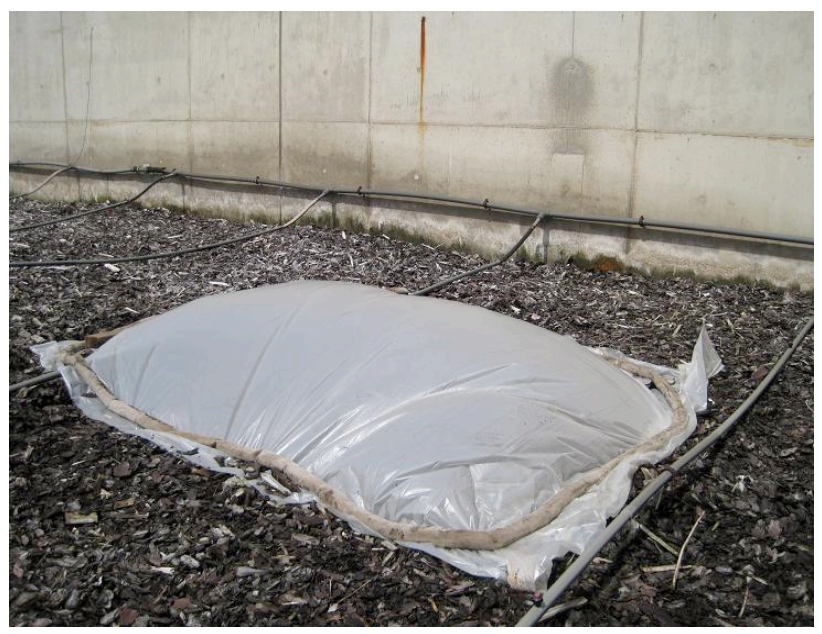

Figure 1: Foil covers on a biofilter for $\mathrm{CH}_{4}, \mathrm{~N}_{2} \mathrm{O}$ and $\mathrm{NH}_{3}$ concentration measurements

\section{Results and discussion}

\subsection{The effects of biofilters on the removal of TOC, NMVOC, $\mathrm{CH}_{4}, \mathrm{NH}_{3}$ and $\mathrm{N}_{2} \mathrm{O}$ in waste air at AD plants}

The concentrations at the inlet and outlet of the biofilters in form of TOC, $\mathrm{NMVOC}, \mathrm{CH}_{4}, \mathrm{NH}_{3}$ and $\mathrm{N}_{2} \mathrm{O}$ are shown in the Figure 2. The concentrations of NMVOC were calculated by subtracting TOC and $\mathrm{CH}_{4}-\mathrm{C}$. Inlet gas contained an average of $151 \mathrm{mg} / \mathrm{m}^{3}$ TOC in the range of $26-$ $333 \mathrm{mg} / \mathrm{m}^{3}$, an average of $150 \mathrm{mg} / \mathrm{m}^{3} \mathrm{NH}_{3}$ in the range of $2.4-1,704 \mathrm{mg} / \mathrm{m}^{3}$ and in average of $2.3 \mathrm{mg} / \mathrm{m}^{3} \mathrm{~N}_{2} \mathrm{O}$ in the range of $0.8-6 \mathrm{mg} / \mathrm{m}^{3}$ and in average of $168 \mathrm{mg} / \mathrm{m}^{3} \mathrm{CH}_{4}$ in the range of $13-380 \mathrm{mg} / \mathrm{m}^{3}$ respectively. The results are in line with those found by Amlinger et al., (2008) and Clemens and Cuhls (2003).

Biofilters reduced TOC, NMVOC and $\mathrm{NH}_{3}$ but were a source for $\mathrm{N}_{2} \mathrm{O}$. Additionally, biofilters reduced $\mathrm{CH}_{4}$ only slightly. Mean relative reductions were 30, 6, 50 and 51\% for TOC, $\mathrm{CH}_{4}, \mathrm{NMVOC}$ and $\mathrm{NH}_{3}$ respectively, whereas $\mathrm{N}_{2} \mathrm{O}$ concentrations were $26 \%$ higher in treated air. The increase of $\mathrm{N}_{2} \mathrm{O}$ may be explained by the fact that $\mathrm{NH}_{3}$ is converted to $\mathrm{N}_{2} \mathrm{O}$ by nitrification due to continuous aerobic conditions in the biofilters (Melse and Van der Werf, 2005). According to previous studies, around one third $\mathrm{NH}_{3}$ that enters biofilters can be transformed and released as $\mathrm{N}_{2} \mathrm{O}$ (Trimborn, 2003). Similarly, Clemens and Cuhls (2003) reported that $26 \%$ of $\mathrm{NH}_{3}$ was transformed into $\mathrm{N}_{2} \mathrm{O}$ in biofilters. The reduction of TOC, $\mathrm{CH}_{4}$ and $\mathrm{NH}_{3}$ were lower than in previous studies (Table 1). Ojstrsek and Fakin (2009) found that TOC removal efficiency of biofilters varied from 31 to $75 \%$. Similarly, Soyez (2002) found that $50 \%$ of TOC was removed in the biofilter. With regard to other literature, $\mathrm{CH}_{4}$ was reduced by $15 \%$ (Amlinger et al., 2008). $\mathrm{NH}_{3}$ was removed in biofilters by more than 90\% (Soyez, 2002; Chen et al., 2005; Hort et al., 2009; Ryu et al., 2011), whereas Akdeniz (2012) found that the reduction efficiency of $\mathrm{NH}_{3}$ were from 53 to $64 \%$ at full-scale biofilters. 


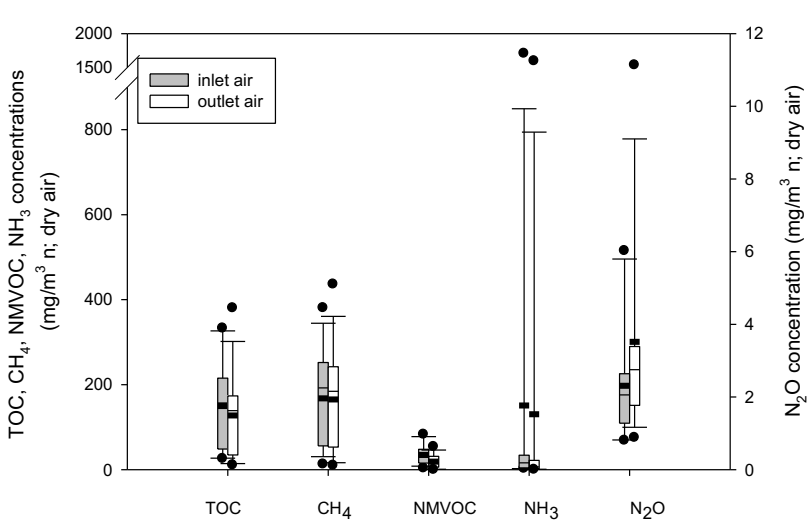

Figure 2. Box plots $(n=15)$ show mean gas concentration values $\left(\mathrm{mg} / \mathrm{m}^{3}\right)$ of treated and untreated air. Box indicates 25 and $75 \%$ percentile; - minimum and maximum of total organic carbon (TOC), methane $\left(\mathrm{CH}_{4}\right)$, non-methane volatile organic carbon (NMVOC), ammonia $\left(\mathrm{NH}_{3}\right)$ and nitrous oxide $\left(\mathrm{N}_{2} \mathrm{O}\right)$.

Table 1: Comparison of removal efficiency of biofilters: this study and data from literature

\begin{tabular}{|c|c|c|c|c|c|}
\hline \multirow[t]{2}{*}{ Authors } & \multicolumn{5}{|c|}{ Removal efficiency of biofilter (\%) } \\
\hline & TOC & $\mathrm{CH}_{4}{ }^{*}$ & NMVOC & $\mathbf{N H}_{3}{ }^{*}$ & $\mathrm{~N}_{2} \mathrm{O}^{*}$ \\
\hline This study & 11 to & 1 to & 11 to 100 & 6.4 to & 0.1 to \\
\hline & 70 & 25 & & 94 & -500 \\
\hline (Soyez, 2002) & 50 & - & 83 & 90 & - \\
\hline (Akdeniz, 2012) & - & - & - & $\begin{array}{c}53 \text { to } \\
64\end{array}$ & -29.2 \\
\hline $\begin{array}{l}\text { (Amlinger et al., } \\
\text { 2008) }\end{array}$ & - & 15 & - & - & - \\
\hline $\begin{array}{l}\text { (Ryu et al., } \\
\text { 2011) }\end{array}$ & $\begin{array}{c}95 \text { to } \\
99\end{array}$ & - & - & 92 & - \\
\hline $\begin{array}{l}\text { (Lopez et al., } \\
\text { 2011) }\end{array}$ & 90 & - & - & - & - \\
\hline $\begin{array}{l}\text { (Hort et al., } \\
\text { 2009) }\end{array}$ & - & - & - & 94 & - \\
\hline $\begin{array}{l}\text { (Chen et al., } \\
\text { 2005) }\end{array}$ & - & - & - & $\begin{array}{c}97 \text { to } \\
99\end{array}$ & - \\
\hline (Ojstrsek and & 31 to & - & - & - & - \\
\hline Fakin, 2009) & 75 & & & & \\
\hline $\begin{array}{l}\text { (Schlegelmilch } \\
\text { et al., 2005) }\end{array}$ & - & - & - & 100 & - \\
\hline $\begin{array}{l}\text { (Clemens and } \\
\text { Cuhls, 2003) }\end{array}$ & - & - & - & $\begin{array}{c}13 \text { to } \\
89\end{array}$ & - \\
\hline $\begin{array}{l}\text { (Trimborn, et } \\
\text { al., 2003) }\end{array}$ & $\begin{array}{c}32 \text { to } \\
78\end{array}$ & $\begin{array}{l}-7 \text { to } \\
26\end{array}$ & 75 to 100 & $\begin{array}{l}-35 \\
\text { to } 91 \\
\end{array}$ & $\begin{array}{c}-9 \text { to }- \\
116 \\
\end{array}$ \\
\hline
\end{tabular}

\subsection{Acid scrubber for $\mathrm{NH}_{3}$ removal}

The inlet concentrations of TOC, $\mathrm{CH}_{4}, \mathrm{NH}_{3}$ and $\mathrm{N}_{2} \mathrm{O}$ were $215,227,24$ and $2.4 \mathrm{mg} \mathrm{m}^{-3}$ respectively (Figure 3 ).

Removal efficiency of the acid scrubber was $48 \%$ for $\mathrm{NH}_{3}$. Concentrations of TOC and $\mathrm{CH}_{4}$ were not significant difference before and after the acid scrubber. Neutral to slightly $\mathrm{N}_{2} \mathrm{O}$ formation from $\mathrm{NH}_{3}$ was found in the outlet gas.

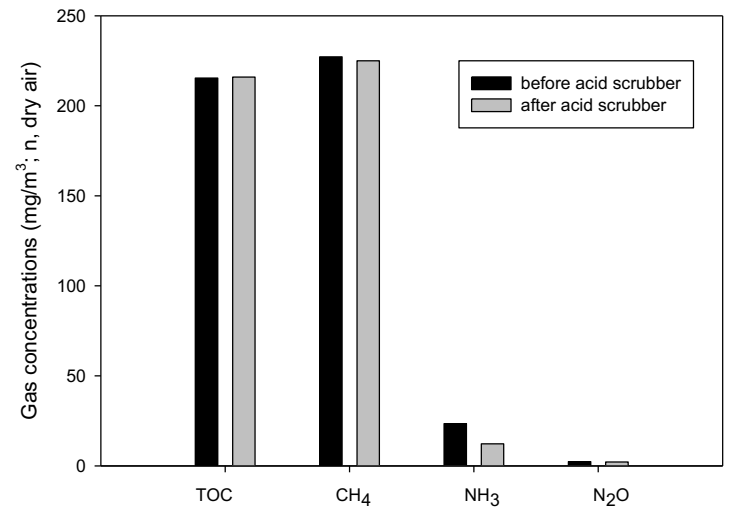

Figure 3. Gas concentrations before and after acid scrubber

\subsection{Purification efficiency of biofilters}

Biofilters showed only a small influence on $\mathrm{CH}_{4}$ emission reduction $(6 \%)$ (Figure 4$)$, whereas they were a source of $\mathrm{N}_{2} \mathrm{O}$ emissions (from 0.1 to $500 \% \mathrm{~N}_{2} \mathrm{O}$ was generated in the biofilters). Biofilters removed significantly TOC $(30 \%)$, NMVOC $(50 \%)$ and $\mathrm{NH}_{3}(51 \%)$.

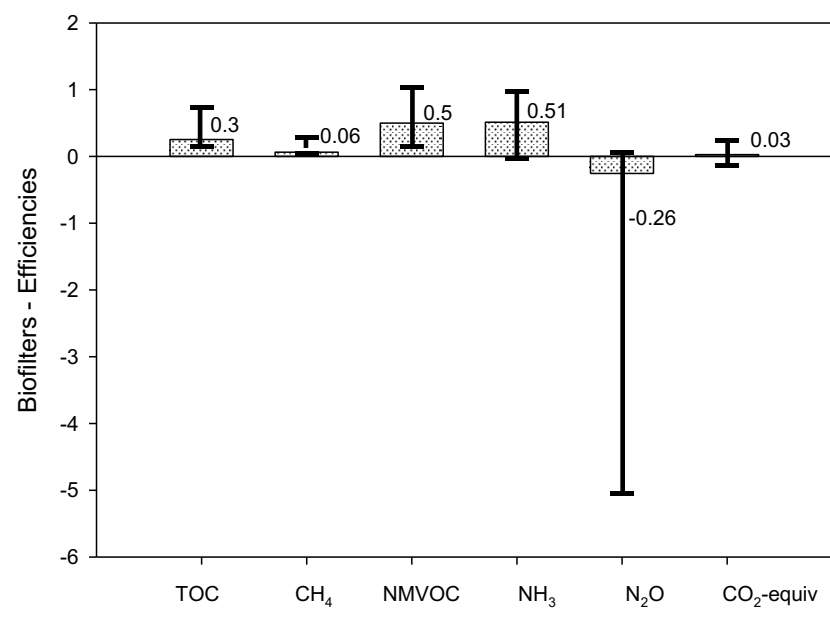

Figure 4. Mean biofilter's efficiencies $(n=15)$ in AD plants. Bars show indicates minimum and maximum values of total organic carbon (TOC), methane $\left(\mathrm{CH}_{4}\right)$, non-methane volatile organic carbon (NMVOC), ammonia $\left(\mathrm{NH}_{3}\right)$ and nitrous oxide $\left(\mathrm{N}_{2} \mathrm{O}\right)$.

The purification efficiency of the analysed biofilters differed. According to IPCC (2007), the emission factors were transferred into $\mathrm{CO}_{2}$ equivalents. Five of fifteen investigated biofilters resulted in higher $\mathrm{CO}_{2}$ equivalents $\mathrm{Mg}^{-1}$ in the exhaust gas as compared to the untreated gas. These five biofilters increased the overall $\mathrm{CO}_{2}$ emissions from 8 to $16 \%$ due to additional $\mathrm{N}_{2} \mathrm{O}$ production. The other ten biofilters showed a positive $\mathrm{CO}_{2}$ equivalents balance and reduced GHG by 0.02 to $21 \%$. 


\section{Conclusions}

In conclusion, biofilters showed an influence on TOC, NMVOC and $\mathrm{NH}_{3}$. However, $\mathrm{N}_{2} \mathrm{O}$ is generated significantly and is the major contributor to the GHG emissions.

There was no significant difference of the treated and untreated $\mathrm{CH}_{4}$ concentrations. Therefore, we conclude that biofilters could not eliminate $\mathrm{CH}_{4}$ concentrations in waste gas.

Biofilter treatment alone shows insignificant GHG emissions reduction. GHG emissions from AD plant can be limited by a combination of acid scrubber and biofilter

\section{References}

[1] Akdeniz, N. J., K. A. 2012. Full-scale biofilter reduction efficiencies assessed using portable 24-hour sampling units. Journal of the Air and Waste Management Association, 62, 170-182.

[2] Amlinger, F., Peyr, S. and Cuhls, C. 2008. Greenhouse gas emissions from composting and mechanical biological treatment. Waste Management and Research, 26, 47-60.

[3] Appels, L., Baeyens, J., Degrève, J. and Dewil, R. 2008. Principles and potential of the anaerobic digestion of waste-activated sludge. Progress in Energy and Combustion Science, 34, 755-781.

[4] Bockreis, A. and Steinberg, I. 2005. Influence of mechanical-biological waste pre-treatment methods on the gas formation in landfills. Waste Management, 25, 337-343.

[5] Bogner, J., Pipatti, R., Hashimoto, S., Diaz, C., Mareckova, K., Diaz, L., Kjeldsen, P., Monni, S., Faaij, A., Qingxian, G., Tianzhu, Z., Mohammed Abdelrafie, A., Sutamihardja, R. T. M. and Gregory, R. 2008. Mitigation of global greenhouse gas emissions from waste: conclusions and strategies from the Intergovernmental Panel on Climate Change (IPCC) Fourth Assessment Report. Working Group III (Mitigation). Waste Management and Research, 26, 11-32.

[6] Chen, Y.-X., Yin, J. and Wang, K.-X. 2005. Longterm operation of biofilters for biological removal of ammonia. Chemosphere, 58, 1023-1030.

[7] Clemens, J. and Cuhls, C. 2003. Greenhouse gas emissions from mechanical and biological waste treatment of municipal waste. Environmental Technology, 24, 745-754.

[8] Deshusses, M. A., Johnson, C. T. and Leson, G. 1999. Biofiltration of high loads of ethyl acetate in the presence of toluene. Journal of the Air and Waste Management Association, 49, 973-979.

[9] Fricke, K., Santen, H. and Wallmann, R. 2005. Comparison of selected aerobic and anaerobic procedures for MSW treatment. Waste Management, $25,799-810$.
[10] Hort, C., Gracy, S., Platel, V. and Moynault, L. 2009. Evaluation of sewage sludge and yard waste compost as a biofilter media for the removal of ammonia and volatile organic sulfur compounds (VOSCs). Chemical Engineering Journal, 152, 4453.

[11] Insam, H. \& Wett, B. 2008. Control of GHG emission at the microbial community level. Waste Management, 28, 699-706.

[12] IPCC. 2007. Climate change 2007- the Physical Science Basis. Contribution of Working Group I to the Fourth Assessment Report of the IPCC. Cambridge University Press, Cambridge, UK.

[13] Mata-Alvarez, J., Macé, S. and Llabrés, P. 2000. Anaerobic digestion of organic solid wastes. An overview of research achievements and perspectives. Bioresource Technology, 74, 3-16.

[14] Melse, R. W. and Van der Werf, A. W. 2005. Biofiltration for mitigation of methane emission from animal husbandry. Environmental Science and Technology, 39, 5460-5468.

[15] Møller, J., Boldrin, A. and Christensen, T. H. 2009. Anaerobic digestion and digestate use: accounting of greenhouse gases and global warming contribution. Waste Management and Research, 27, 813-824.

[16] Ojstrsek, A. and Fakin, D. 2009. Colour and TOC reduction using biofilter packed with natural zeolite for the treatment of textile wastewaters. Desalination and Water Treatment, 33, 147-155.

[17] Ryu, H. W., Cho, K. S. and Lee, T. H. 2011. Reduction of ammonia and volatile organic compounds from food waste-composting facilities using a novel anti-clogging biofilter system. Bioresource Technology, 102, 4654-4660.

[18] Sanscartier, D., Maclean, H. L. and Saville, B. 2011. Electricity Production from Anaerobic Digestion of Household Organic Waste in Ontario: TechnoEconomic and GHG Emission Analyses. Environmental Science and Technology, 46, 1233-1242.

[19] Schlegelmilch, M., Streese, J., Biedermann, W., Herold, T. and Stegmann, R. 2005. Odour control at biowaste composting facilities. Waste Management, 25, 917-927.

[20] Soyez, K., Plickert, S. 2002. Mechanical-Biological Pre-Treatment of Waste - State of the Art and Potentials of Biotechnology. Universität Potsdam.

[21] Trimborn, M., Goldbach, H., Clemens, J., Cuhls, C. and Breeger, A., 2003. Reduction of greenhouse gases in the exhaust air of biofilters at biowaste treatment plants. In: Band 14 der Bonner Agrikulturchemischen Reihe, Abschlußbericht

[22] Zupančiča, G. D., Uranjek-Ževartb., Nataša, Roša., Milenko 2008. Full-scale anaerobic co- digestion of organic waste and municipal sludge. Biomass and Bioenergy, 32, 162-167. 